Available online at website :

http://e-journal.adpgmiindonesia.com/index.php/jmie

JMIE: Journal of Madrasah Ibtidaiyah Education, 4(2), 2020, 272-282

\title{
PENGARUH MODEL COOPERATIVE LEARNING TIPE SNOWBALL THROWING TERHADAP KEMAMPUAN BERBICARA PESERTA DIDIK KELAS V SEKOLAH DASAR
}

\author{
Anggy Giri Prawiyogi' ${ }^{1}$ Ratnasari Pertiwi², Rahman ${ }^{3}$, Andoyo Sastromiharjo ${ }^{4}$ \\ Universitas Buana Perjuangan Karawang ${ }^{1}$, Universitas Buana Perjuangan Karawang ${ }^{2}$, \\ Universitas Pendidikan Indonesia ${ }^{3}$, Universitas Pendidikan Indonesia ${ }^{4}$ \\ e-mail Anggy.Prawiyogi@ubpkarawang.ac.id ${ }^{1}$, ratnasp@student.upi.edu², \\ rahmanprof@upi.edu ${ }^{3}$, andoyo@upi.edu ${ }^{4}$
}

Submit: 3 Juni 2020, Revisi: 1 Oktober 2020, Approve: 12 November 2020

\begin{abstract}
This research is motivated by a lack of student participation in classroom learning because of students' ability to learn about different teaching materials, remain embarrassed and confused when saying or speaking in front of the class. The purpose of this research is to know the improvement and influence of "Cooperative learning" model of "Snowbal throwing" type to students'speech on the theme of our friend's environment in elementary school.The method used in this research is quasi experimental with design "The no-equivalent pretest-posttest control group design.” This research was conducted at Cikampek Pusaka I State Elementary School (SDN Cikampek Pusaka I), Cikampek District, Karawang Regency. The participants in this research were students of grade $\mathrm{V}$, with sample of experiment class and control class each 20 students. The research instrument used is the instrument of speech.Data analysis using parametric statistic test, based on result of experiment class and control class analysis showed that there was an improvement of speech ability between the two classes, where the experiment class improvement was 0.64 and included in medium category, while in the control class the improvement of speech ability was 0.23 and included in low category. Besides, based on the regression analysis, it is found that the model of "cooperative learning"type "Snowball throwing" effect on students'speech ability with the percentage of $36.1201 \%$. The findings qualitatively show a significant impact on students'speech so that it becomes increasing. Thus the model "Cooperative learning" type "snowball throwing" can influence and train students to improve speech ability significantly.
\end{abstract}

Keywords: Speech Ability, Cooperative Learning, Snowball Throwing

Pengutipan: Anggy Giri Prawiyogi, dkk. (2020). Pengaruh Model Cooperative Learning Tipe Snowball Throwing terhadap Kemampuan Berbicara Peserta Didik Kelas V Sekolah Dasar. JMIE: Journal of Madrasah Ibtidaiyah Education, 4(2), 2020, 272-282. jmie.v4i2.186.

Permalink/DOI: $\underline{\text { http://dx.doi.org/10.32934/jmie.v4i2.186 }}$ 


\section{PENDAHULUAN}

Pendidikan pada dasarnya adalah untuk memaksimalkan potensi yang ada pada anak didik melalui proses pembelajaran yang berjenjang mulai taman kanak-kanak/paud, sekolah dasar (SD), sekolah menengah pertama (SMP), sekolah menengah atas (SMA), dan perguruan tinggi (PT/Univeritas). Tujuan pendidikan sesuai dengan Undang-undang yaitu tujuan pendidikan nasional adalah untuk mengembangkan potensi peserta didik agar menjadi manusia yang beriman dan bertakwa kepada Tuhan Yang Maha Esa, berakhlak mulia, sehat, berilmu, cakap, kreatif, mandiri, dan menjadi warga negara yang demokratis serta bertanggung jawab (UU No.20, 2013). Di dalamnya ada berilmu, cakap dan kreatif, sesuai dengan penelitian yang diangkat oleh peneliti dalam artikel ini. Sedangkan Hakekat pembelajaran menurut Hernawan dkk. (2007, hlm.3) adalah sebuah alur komunikasi yang terjadi antara pendidik dan peserta didik di dalam alur tersebut terjadi komunikasi berbalasan antara pendidik dan peserta didik mengenai ilmu yang diberikan dan/ diterima oelh kedua pihak. Komunikasi yang baik dalam proses pembelajaran adanya komunikasi dua arah, dimana komunikan memahami isi pembicaraan yang diucapkan oleh komunikator. Pendidik merupakan komunikator dalam proses belajar mengajar di dalam kelas dan peserta didik merupakan komunikan.

Dalam proses pembelajaran pada saat ini sumber belajar tidak hanya berasal dari guru namun dapat ditemukan di lingkungan sekitar peserta didik itu sendiri. Sehingga proses pembelajaran lebih ditekankan peserta didik sebagai pusat belajar, dimana peserta didik belajar mencari tahu sendiri tentang materi yang dipelajari seperti ilmu pendidikan alam (IPA), bahasa Indonesia, dan Ilmu Pengetahuan Sosial (IPS), serta mata pelajaran yang lainnya dengan diarahkan pendekatan saintifik (mengamati, menanya, mencoba, mengasosiasi dan mengkomunikasikan) dimana pembelajaran akan lebih bermakna.

Dalam kurikulum 2013 terdapat kompetensi inti (KI) yaitu, 1) sikap spiritual, 2) sikap sosial, 3) pengetahuan, dan 4) keterampilan. Dalam kompetensi inti mengenai keterampilan dibutuhkan cara komunikasi yang baik dengan ditunjang kemampuan berbicara peserta didik yang baik pula. Diungkapkan oleh Nurgiyantoro (2014) bahwa berbicara adalah suatu proses kegiatan bercakap-cakap yang sering diucapkan berulang kali oleh seseorang sesudah ia melakukan kegiatan mendengarkan. Berdasarkan hal-hal yang didengarkan itulah kemudian seseorang berlatih mengungkapkan hal-hal yang ia tahu dan akhirnya mampu untuk berbicara. Keberhasilan suatu kompetensi dapat tercapai atau tidaknya oleh peserta didik bergantung kepada guru dalam menyelaraskan perkembangan kemampuan dasar secara optimal, sehingga diperlukan kreativitas guru untuk memilih alternatif model pembelajaran agar proses belajar mengajar lebih efektif.

Kemampuan berbicara menurut Tarigan $(1998,15)$ yaitu kecakapan melisankan lafal pengejaan atau kalimat guna mengungkapkan, memberitahukan serta menyalurkan ide, gagasan dan perasaan. Sehingga diperoleh kesimpulan bahwa kemampuan berbicara seseorang 
merupakan cerminan pikirannya. Semakin banyak pengetahuan seseorang maka semakin banyak kosa kata yang ia miliki dan hal tersebut mempengaruhi kemampuan berbicara orang tersebut. Pendapat lain dikemukakan oleh Abidin, dkk (2015) bahwa kemampuan berbicara adalah kemampuan mengucapkan bunyi-bunyi artikulasi atau mengucapkan kata-kata untuk mengekspresikan, menyatakan, menyampaikan pikiran, gagasan, dan perasaan. pendengar menerima informasi melalui rangkaian nada, tekanan, dan penempatan persendian (juncture)

Kemampuan berbicara dapat dikatakan berhasil apabila 1) Jelas pelafalannya, 2) Baik tata bahasanya, 3) Terstruktur kosa katanya, 4) Kefasihan dalam berbicara (kemudahan dan ketepatan dalam berbicara), dan 5) Pemahaman dari apa yang dibicarakan. (Fazari, 2012: 22-24). Artinya dikatakan mampu dalam berbicara didepan umum apabila menguasai 5 (lima) indikator tersebut.

Berdasarkan observasi awal pada kelas V SDN Cikampek Pusaka I ditemukan kurangnya kemampuan berbicara siswa, hal tersebut dibuktikan dengan partisipasi siswa dalam pembelajaran berlangsung masih rendah.

Salah satu cara untuk meningkatkan kemampuan berbicara pada peserta didik kelas $\mathrm{V}$ yaitu dengan mengembangkan strategi pembelajaran dengan menggunakan model cooperative learning tipe snowball throwing, Menurut Slavin (2005) mengungkapkan untuk mewujudkan caracara pembelajaran kooperatif yang mengurut atau tersusun dengan rapih dan efisien yang akan dimanfaatkan oleh pendidik untuk mendapatkan pengelolaan kelas yang tepat. Sejalan dengan itu Lestari dan Yudhanegara (2017) mengungkapkan bahwa model cooperative learning tipe snowball throwing menitikberatkan pada keterampilan merumuskan pertanyaan dengan teknik bermain saling melempar bola pertanyaan pada temannya sehingga mau tidak mau peserta didik yang mendapatkan pertanyaan harus menjawab secara lisan atau berujar.

Berdasarkan hasil observasi awal tersebut, peneliti ingin meneliti tentang bagaimana pengaruh dan peningkatan pada penerapan model cooperative learning tipe snowball throwing terhadap kemampuan berbicara peserta didik pada tema lingkungan sahabat kita di kelas V SDN Cikampek Pusaka I ?

Dengan tujuan penelitian untuk mengetahui peningkatan kemampuan berbicara peserta didik melalui penerapan model cooperative learning tipe snowball throwing pada tema lingkungan sahabat kita di sekolah dasar dan juga untuk mengetahui ada atau tidaknya pengaruh model cooperative learning tipe snowball throwing terhadap kemampuan berbicara peserta didik pada tema lingkungan sahabat kita di sekolah.

Pembelajaran kooperatif menurut Huda (2015, 32) mencontohkan pada mekanisme pembelajaran dengan peserta didik berkolaborasi ketika disatukan ke grup yang sama dan saling tolong-menolong ketika proses pembelajaran. Cooperative learning adalah model pembelajaran yang berbasis kerja sama tim atau grup, yang masing-masing grup minimal beranggotakan dari empat atau lima orang dengan tujuan belajar bersama (Suparmi, 2012: 108-118). 
Langkah-langkah model cooperative learning menurut Asmani (2016) diantaranya, memberitahukan maksud pembelajaran dan semangat kepada peserta didik, mengemukakan penjelasan mengenai materi ajar, mengatur peserta didik ke dalam grup-grup belajar, memberikan arahan ke setiap grup-grup belajar, memberikan ulasan mengenai pembelajaran hari ini, menghadiahkan penilaian atau apresiasi terhadap peserta didik yang telah mengikuti pembelajaran dengan tertib dan baik. Sehingga dapat disimpulkan bahwa langkah-langkah pembelajaran model cooperative learning diantaranya: 1) memilih metode, teknik, dan struktur pembelajaran kooperatif, 2) mempersiapkan pembelajaran kooperatif, 3) menyampaikan tujuan, 4) mengemukakan penjelasan mengenai materi, 5) mengatur peserta didik ke dalam grup-grup belajar, 6) membagikan lembar kerja peserta didik, 7) menilai kegiatan pembelajaran, 8) memberikan penghargaan pada kelompok, 9) mengevaluasi perilaku-perilaku anggota kelompok.

Model pembelajaran snowball throwing menurut Munawaroh dan Alamuddin (2014) bermanfaat bagi peserta didik dalam mengasah kepekaan serta pemahaman peserta didik ketika memperoleh pertanyaan dari peserta didik lainnya yang berwujud bulat seperti salju, dan menginformasikan materi yang ia tahu kepada temannya di satu grup belajar. Sejalan dengan pendapat ahli di atas model cooperative learning adalah pembelajaran kooperatif yang memberikan kesempatan kepada peserta didik untuk mengembangkan keterampilan menyimpulkan isi berita atau informasi yang mereka peroleh dengan melatih daya tanggap peserta didik melalui pertanyaan-pertanyaan yang dibuat oleh peserta didik yang lainnya sehingga pembelajaran lebih menarik dan menyenangkan. Model pembelajaran Snowball Throwing melatih siswa untuk lebih tanggap menerima pesan dari orang lain dan menyampaikan pesan tersebut kepada temannya dalam satu kelompok (Apriani, dkk: 2017: 1-11, Rosidah, 2017: 29-36). Selanjutnya, menurut Gustomo, di dalam pembelajaran yang menggunakan model pembelajaran Snowball Throwing, model pembelajaran tersebut memberikan motivasi tersendiri kepada para siswa. Hal tersebut terlihat dari respon yang didapat melalui model pembelajaran Snowball Throwing (2015, 59-63).

Langkah-langkah pembelajaran model snowball throwing yiatu: 1) guru menyampaikan materi yang disajikan, 2) guru membagi kelompok-kelompok belajar, 3) masing-masing ketua diberikan arahan oleh guru mengenai materi yang akan di bahas, 4) kemudian masing-masing ketua menjelaskan materi kepada teman-teman sekelompoknya, 5) kemudian guru memberikan arahan kepada setiap peserta didik untuk menuliskan satu pertanyaan pada selembar kertas, 6) lalu kertas pertanyaan tersebut dibuat seperti bola salju dan kemudian dilemparkan kepada peserta didik lain selama \pm 15 menit, 7) setiap peserta didik yang mendapatkan pertanyaan diberikan kesempatan untuk menjawab setiap pertanyaan tersebut, 8) guru mengevaluasi setiap peserta didik yang masih kurang tepat dalam menjawab pertanyaan.

Siti Nurkhoyah dalam penelitiannya yang berjudul Penerapan Metode Snowball Throwing Dalam Peningkatan Keterampilan Berbicara Pada Siswa Kelas III MI Pembangunan UIN Jakarta menunjukkan hasil penelitiannya bahwa penerapan metode snowball throwing dapat meningkatkan 
keterampilan berbicara siswa dilihat dari peningkatan nilai rata-rata pada siklus I sebesar 69,5 menjadi 74,3 pada siklus II yang mengalami peningkatan 4,8. Selain itu, penerapan metode snowball throwing juga dapat meningkatkan aktivitas belajar siswa. Hal ini terlihat dari persentase aktivitas belajar pada siklus I sebesar 45,7\% menjadi 79,4\% pada siklus II yang mengalami peningkatan dari siklus I ke siklus II sebnayak 33,7\%.

Dea Suresna Puspita, dkk (2015) mengatakan pada penelitiannya yang berjudul Pengaruh Model Pembelajaran Kooperatif Tipe Snowball Throwing Terhadap Peningkatan Kemampuan Berbicara pada Mata Pelajaran Bahasa Indonesia Siswa Kelas V SDN Sumbersari 01 Jember. Berdasarkan perhitungan uji efektivitas relatif (ER) menyatakan bahwa kelas yang pembelajarannya menggunakan model pembelajaran kooperatif tipe Snowball Throwing lebih efektif $9.268 \%$ dibandingkan kelas yang pembelajarannya menggunakan metode ceramah, diskusi dan tanya jawab.

Selain itu diperkuat dengan penelitian dari Yulia Kusumayanti, dkk yang berjudul Pengaruh Model Pembelajaran Snowball Throwing Berbantuan Media Konkeret Terbadap Hasil Belajar IPA Siswa Kelas V Di Gugus V Kecamatan Sukasada menunjukkan hasil yang sama bahwa terdapat perbedaan hasil belajar antara siswa yang belajar dengan model pembelajaran Snowball Throwing berbantuan media konkret dan siswa yang belajar dengan model pembelajaran konvensional. Hal ini terlihat dari hasil analisis uji-t dengan thitung lebih besar dari ttabel yaitu 1,95146> 1,67109 dengan derajat kebebasan 59 dan rata-rata skor hasil belajar IPA kelompok siswa yang belajar dengan model pembelajaran Snowball Throwing berbantuan media konkret adalah 23,78 berada pada katagori sangat tinggi dan rata-rata skor hasil belajar IPA kelompok siswa yang belajar dengan model pembelajaran konvensional adalah 17,51 berada pada katagori tinggi. Model pembelajaran Snowball Throwing berbantuan media konkret terbukti lebih unggul 6,27 dibandingkan dengan model pembelajaran konvensional.

Penerapan model cooperative learning tipe snowball throwing dapat diterapkan dengan pembelajaran tematik. Departemen Pendidikan Nasional (Depdiknas) dalam buku Abdul Majid (2017, hlm 4) mengungkapkan bahwa pembelajaran tematik adalah salah satu cara pembelajaran yang mengintegrasikan beberapa mata pelajaran dalam suatu tema tertentu dengan konten praktek yang lebih mendominasi dibandingakan dengan materi yang disajikan dalam kelas sehingga peserta didik dapat merasakan secara langsung bagaimana keterikatan materi yang ia pelajari dengan kehidupan nyata di lingkungannya setiap hari yang menjadikan hal tersebut pengalaman yang nyata bagi peserta didik agar mereka mudah dalam mengingat materi yang diajarkan oleh guru. Mata pelajaran yang diintegrasikan berdampak pada alokasi waktu di setiap pembelajaran serta kebijakan yang diambil oleh setiap lembaga kependidikan (kurikulum) atau pun hal lainnya yang dapat menunjang jalannya pembelajaran tematik. Pada masa kini pembelajaran tematik terimplementasikan dengan adanya kurikulum 2013 yang bersifat tematik integrative pada jenjang pendidikan sekolah dasar. 
Kelas V semester II tema yang dipelajari adalah mengenai Lingkungan Sahabat Kita (tema 8) dan Benda-Benda di Sekitar Kita (tema 9). Peneliti hanya akan terfokus pada tema 8 dengan sub tema 1 yaitu mengenai Manusia dan Lingkungan. Dengan 4 kompetensi inti yang dimiliki di setiap pembelajarannya. Terutama pada kompetensi inti mengenai keterampilan. Salah satu keterampilan yang sangat dibutuhkan dalam berkomunikasi dengan baik yaitu kemampuan berbicara peserta didik yang baik pula.

\section{METODE PENELITIAN}

Desain penelitian yang digunakan dalam menggunakan the non-equivalent pretest-posttest control group desain. Desain penelitian ini terdiri dari kelompok kontrol dan kelompok eksperimen. Kedua kelompok tersebut kemudian diberi tes awal untuk mengetahui keadaan awal, apakah kedua kelompok tersebut sama, adakah perbedaan antara kelompok kontrol dan kelompok eksperimen. Setelah itu masing-masing diberi perlakuan, kelompok pertama dengan perlakuan pembelajaran kemampuan berbicara menggunakan model cooperative learning tipe snowball throeing disebut kelompok eksperimen dan kelompok kedua dengan pembelajaran kemampuan berbicara tidak menggunakan model cooperative learning tipe snowball throwing disebut kelompok kontrol.

Kemudian pada akhir pembelajaran, peserta didik mengerjakan tes akhir dengan menggunakan soal yang sama untuk mengetahui pengaruh model cooperatve learning tipe snowball throwing pada kemampuan berbicara peserta didik pada sub tema Manusia dan Lingkungan. Dan penelitian ini melibatkan partisipan dari kelas V sekolah dasar di SDN Cikampek Pusaka I di Kecamatan Cikampek Kabupaten Karawang. Terdapat dua kelompok dalam penelitian yaitu kelas V A yang menjadi kelompok kontrol dan yang kedua kelas V B yang menjadi kelompok eksperimen atau yang mendapatkan perlakuan dengan menerapkan model cooperative learning tipe snowball throwing pada sub tema Manusia dan Lingkungan.

Instrumen dalam penelitian ini menggunakan instrumen penelitian kuantitatif dan instrumen penelitian kualitatif. Teknik tes yang digunakan pada penelitian ini menggunakan instrumen penilaian kemampuan berbicara dengan lembar penilaian tes kemmapuan berbicara. Sedangkan untuk non tes digunakan untuk memperoleh gamabaran secara menyuluruh peneliti menggunakan dokumen foto dan rekaman video atau audio.

Jenis data yang diperoleh dari penelitian ini terdiri dari dua jenis yaitu data kuantitatif dan kualitatif (mix metode). Data kuantitatif diperoleh dari hasil tes awal dan tes akhir, sedangkan data kuantitatif diperoleh dari hasil dokumentasi atau foto kegiatan pembelajaran. Penyajian data hasil penelitian dilakukan dengan analisis deskriptif dan analisis inferensial.

Analisis deskriptif untuk mengetahui peningkatan kemampuan berbicara peserta didik dilihat melalui skor gain ternormalisasi. Sedangkan analisis inferensial dilakukan untuk 
menganalisis secara statistik peningkatan dan pengaruh model cooperative learning tipe snowball throwing terhadap kemampuan berbicara peserta didik.

Prosedur penelitian ini dimulai mengidentifikasi masalah dan melakukan observasi awal, kemudian peneliti melakukan pretest. Setelah itu peneliti menentukan kelompok yang menjadi kelompok kontrol dan kelompok yang menjadi kelompok eksperimen. Kemudian kelas kontrol melakukan proses pembelajaran dengan tidak menggunakan model cooperative learning tipe snowball throwing, sedangkan pada kelas eksperimen melakukan proses pembelajaran dengan menggunakan model cooperative learning tipe snowball throwing. Lalu peneliti melakukan posttest dengan menggunakan soal yang sama. Kemudian dilakukan uji data dan ditarik kesimpulan dari hasil data tersebut.

\section{HASIL DAN PEMBAHASAN}

Hasil penelitian yang dilakukan diperoleh data untuk menganalisis peningkatan kemampuan berbicara. Untuk mencari peningkatan kemampuan berbicara antara kelas kontrol dan kelas eksperimen di awali dengan cara mencari N-Gain dari hasil pretest dan hasil posttest di kelas kontrol maupun eksperimen. Rekapitulasi data peningkatan kemampuan berbicara berdasarkan hasil test ditunjukkan oleh tabel 1

Tabel 1. Rekapitulasi Data Peningkatan Kemampuan Berbicara Berdasarkan Hasil Test

\begin{tabular}{lllllll}
\hline \multirow{2}{*}{ Data } & \multirow{2}{*}{ Kelas } & \multicolumn{2}{c}{ Skor } & \multirow{2}{*}{ Sd } & \multirow{N}{*}{-gain } \\
\cline { 3 - 5 } & & Terkecil & Terbesar & & & \\
\hline Pretest & \multirow{2}{*}{ Eksperimen } & 15 & 32 & 22,40 & 5,68 & \multirow{2}{*}{0,64} \\
Posttest & 27 & 38 & 32,90 & 3,32 & \\
Pretest & Kontrol & 20 & 31 & 23,65 & 2,90 & \multirow{2}{*}{0,23} \\
Posttest & 23 & 36 & 27,00 & 2,69 & \\
\hline
\end{tabular}

(Sumber: Hasil Penelitian 2018)

Bersumber pada tabel 1 tampak bahwa peningkatan kemampuan berbicara peserta didik yang mendapatkan pembelajaran dengan menggunakan model cooperative learning tipe snowball throwing lebih tinggi dari peserta didik yang tidak mendapatkan pembelajaran dengan menggunakan model cooperative learning tipe snowball throwing.

Sedangkan untuk mengetahui pengaruh model cooperative learning tipe snowball throwing terhadap kemampuan berbicara maka dilakukan uji beda rata-rata. Rekapitulasi uji beda ratarata pengaruh model cooperative learning tipe snowball throwing terhadap kemampuan berbicara peserta didik berdasarkan hasil test diperoleh data yang tertera tabel 2 sebagai berikut. 


\section{Tabel 2. Uji Perbedaan Rata-rata Peningkatan Keterampilan Sosial Berdasarkan Pembelajaran Ditinjau Secara Pembelajaran}

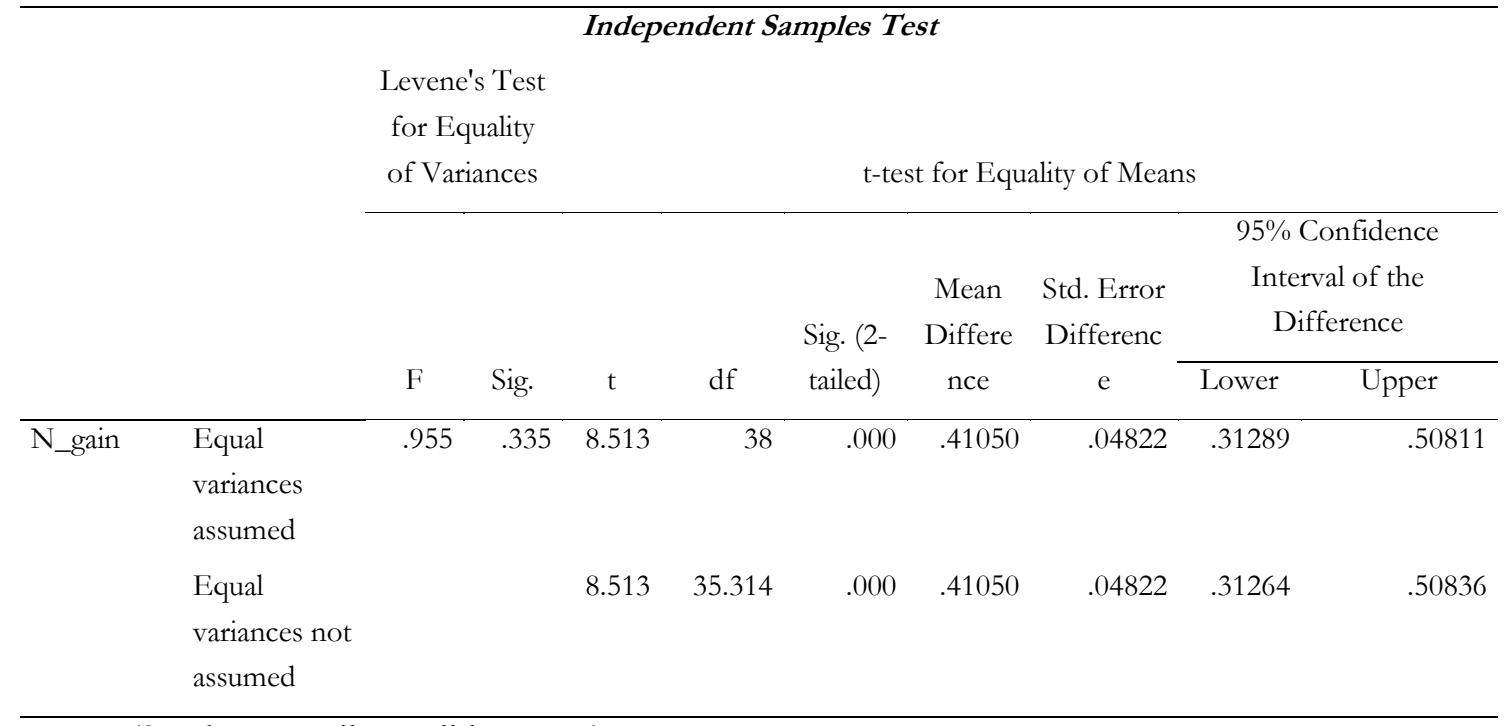

(Sumber : Hasil Penelitian 2018)

Berdasarkan hasil perhitungan pada tabel 4.3 dapat dilihat bahwa untuk rata-rata peningkatan kemampuan berbicara siswap-value (sig.2-arah) adalah 0,000 lebih kecil dari 0,05 maka di H0 ditolak. Artinya jika ditinjau dari hasil tes, peningkatan kemampuan berbicara siswa yang mendapatkan pembelajaran dengan model cooperative learning tipe snowball throwing lebih baik secara signifikan dibandingkan siswa yang tidak mendapatkan pembelajarandengan model cooperative learning tipe snowball throwing.

Pembelajaran dengan menggunakan model cooperative learning tipe snowball throwing pada penelitian ini telah dirancang untuk meningkatkan kemampuan berbicara peserta didik. pembelajaran ini disajikan dalam bentuk kerja sama kelompok untuk memahami suatu teks tentang manusia dan lingkungan sesuai dengan buku peserta didik tema 8 sub tema 1 dengan bermain melempar bola pertanyaan. Peserta didik yang mengikuti pembelajaran ini diatur dalam kelompok-kelompok yang berjumlah 5 atau 6 orang dengan kemampuan peserta didik yang heterogen.

Pembelajaran tematik pada sub tema manusia dan lingkungan dengan menerpakan model cooperative learning tipe snowball throwing pada peserta didik kelas V di SDN Cikampek Pusaka I menunjukan peningkatan kemampuan berbicara. Hal ini sesuai dengan hasil penelitian yang relevan dari Dea Suresna Puspita dkk (2015) "Pengaruh Model Pembelajaran Kooperatif Tipe Snowball Throwing Terhadap Peningkatan Kemampuan Berbicara Pada Mata Pelajaran Bahasa Indonesia Peserta didik Kelas V SDN Sumbersari 01 Jember”. Hasil penelitian ternyata sungguh dapat meningkatkan kemampuan berbicara peserta didik. 
Peningkatan kemampuan berbicara peserta didik dapat diukur melalui tiga aspek yaitu bahasa lisan, isi pembicaraan, dan teknik penampilan. Ketiga aspek tersebut memiliki beberapa indikator yaitu lafal dan intonasi, pilihan kata, struktur bahasa, gaya bahasa, hubungan isi topik, struktur isi, kuantitas isi, kualitas isi, gerak-gerik dan mimik, ketepatan kalimat, hubungan dengan pendengar, volume suara, serta jalannya pembicaraan.

Sejalan dengan itu tujuan berbicara di kelas tinggi menurut Solchan dkk (2009, hlm. 120121) yaitu membentuk rasa percaya diri peserta didik, menyampaikan informasi dan pemahaman peserta didik, mengasah peserta didik menyangkal/membantah anggapan oaring lain, mengasah peserta didik untuk berasumsi responsif dan rasional, serta mengasah peserta didik agar memperhitungkan anggapan orang lain sehingga tidak memandang sebelah pihak. Melalui model cooperative learning tipe snowball throwing ini peserta didik mendapatkan wawasan yang lebih luas tidak hanya dari guru namun dari teman-temannya melalui bermain bola pertanyaan sehingga pembelajaran pun lebih menyenangkan, tidak membosankan, tidak membuat peserta didik mengantuk dalam pembelajaran sehingga waktu dalam pembelajaran lebih efektif. Tidak hanya pengetahuan model ini pun mengasah responsive atau kepekaan peserta didik dalam menerima atau menjawab bola pertanyaan dari teman-temannya .

Berdasarkan deskripsi tersebut, maka model cooperative learning tipe snowball throwing dapat meningkatkan kemampuan berbicara peserta didik pada tema Lingkungan Sahabat Kita dengan Sub Tema Manusia dan Lingkungan sebesar 0,64. Sehingga dapat disimpulkan bahwa model cooperative learning tipe snowball throwing dapat juga memberikan pengaruh terhadap kemampuan berbicara peserta didik sebesar 36, 1201\% dan besarnya pengaruh faktor lain yaitu sebesar $63,8799 \%$.

\section{SIMPULAN}

Simpulan dari penelitian ini adalah 1) Model Cooperative Learning tipe Snowball Throwing dapat meningkatkan kemampuan berbicara peserta didik pada tema Lingkungan Sahabat Kita pada sub tema Manusai dan Lingkungan di kelas V SDN Cikampek Pusaka I Kecamatan Cikampek Kabupaten Karawang, 2) Model Cooperative Learning tipe Snowball Throwing dapat memberikan pengaruh terhadap kemampuan berbicara peserta didik pada tema Lingkungan Sahabat Kita pada sub tema Manusia dan Lingkungan di kelas V SDN Cikampek Pusaka I Kecamatan Cikampek Kabupaten Karwang. 


\section{DAFTAR PUSTAKA}

Abidin, Zainal, dkk. (2015). Peningkatan Kemampuan Berbicara Pembelajaran Bahasa Indonesia Dengan Teknik Bercerita (Story Telling) Pada Sekolah Dasar. Jurnal Pendidikan dan Pembelajaran, Vol. 4 (10), hal. 1-13.

Apriani, Ni Komang Purnami, dkk. (2017). Pengaruh Model Pembelajaran Snowball Throwing Terhadap Hasil Belajar IPS Siswa Kelas V SD. Mimbar PGSD, Vol 5 (2), hal. 1-11.

Asmani, Jamal Ma'mur. (2016). Tips Efektif Cooperative Learning. Yogyakarta: DIVA Press

Fazari. (2012). Peningkatan Kemampuan Berbicara Melalui Metode Simulasi Siswa Kelas IV Madrasah Ibtidaiyah Tarbiyah Islamiah Bente Berkat Kecamatan Mandah Kabupaten Indragiri Hilir. Skripsi. Fakultas Tarbiyah dan Keguruan UIN Syarif Kasim Riau.

Gustomo, Ade dan Sudarman. (2015). Penerapan Model Pembelajaran Snowball Throwing untuk Meningkatkan Hasil Belajar Siswa pada Kompetensi Memperbaiki Unit Kopling dan Komponen-Komponen Sistem Pengoperasian. Jurnal Pendidikan Teknik Mesin, Vol. 15 (2), hal. 59-63.

Hernawan, A. H dkk. (2007). Belajar dan Pembelajran Sekolah Dasar. Bandung: UPI PRESS

Huda, M. (2015). Cooperative Learning, Metode, Teknik, Struktur, dan Model Penerapan.Yogyakarta: Pustaka Pelajar

Kusumayanti, Dsk.Pt. Yulia. (2013). Pengaruh Model Pembelajaran Snowball Throwing Berbantuan Media Konkret terhadap Hasil Belajar IPA Siswa Kelas V di Gugus V Kecamatan Sukasada. Jurnal Mimbar PGSD, Volume I. (Online). (http:/ / ejournal.undiksha.ac.id/index.php/JJPGSD/article/view/870)

Lestari, K. dan Yudhanegara, M. (2017). Penelitian Pendidikan Matematika. Bandung: Refika Adhitama

Majid, Abdul. (2017). Pembelajaran Tematik Terpadu.Bandung: PT. Remaja Rosdakarya

Munawaroh, M dan Alamuddin A. (2014). Pengaruh Penerapan Model Snowball Throwing Terhadap Hasil Belajar Matematika Peserta didik dengan Pokok Bahasan Relasi dan Fungsi (Jurnal). [Online]. Tersedia : M Munawaroh, A Alamuddin-Eduma:MathematicsEducation...,2014syek.hnurjati.ac.id. [7 Desember 2017]

Nurgiyantoro, Burhan. (2014). Penilaian Pembelajaran Bahasa Berbasis Kompetensi. Yogyakarta : BPFE

Paelatun, Siti Nurkhoyah. (2014). Penerapan Metode Snowball Throwing Dalam Peningkatan Keterampilan Berbicara Pada Siswa Kelas III MI Pembangunan UIN Jakarta. Skripsi. UIN Syarif Hidayatullah Jakarta 
Anggy Giri Prawiyogi, dkk

Puspita, Dea Suresna, dkk (2015). Pengaruh Model Pembelajaran Kooperatif Tipe Snowball Throwing Terhadap Peningkatan Kemampuan Berbicara pada Mata Pelajaran Bahasa Indonesia Siswa Kelas V SDN Sumbersari 01 Jember. Skripsi. Universitas Jember

Rosidah, Ani. (2017). Penerapan Model Pembelajaran Kooperatif Snowball Throwing untuk Meningkatkan Hasil Belajar Siswa Pada Pembelajaran IPS. Jurnal Cakrawala Pendas, Vol. 3(1), 29-36.

Slavin, Robert E. (2005). Cooperative Learning. Bandung: Nusa Media

Solchan, T dkk. (2009). Pendidikan Bahasa Indonesia di SD. Jakarta:Universitas terbuka

Suparmi. (2012). Pembelajaran Kooperatif dalam Pendidikan Multikultural. Jurnal Pembangunan Pendidikan: Fondasi dan Aplikasi, Vol. 1 (1), hal. 108-118.

Tarigan, H.G. (2008). Berbicara sebagai suatu Keterampilan Berbahasa. Bandung : Angkasa

UU No. 20 Tahun 2003 pasal 3 Tentang Sistem Pendidikan Nasional 